\title{
LAND-OCEAN FLUXES IN THE PARANAGUÁ BAY ESTUARINE SYSTEM, SOUTHERN BRAZIL
}

\author{
Eduardo Marone ${ }^{I}$; Eunice C. Machado ${ }^{\text {; Rubens M. } \text { Lopes }^{2} \text { \& Eduardo Teixeira da Silva }}{ }^{l}$ \\ ${ }^{1}$ Centro de Estudos do Mar da Universidade Federal do Paraná \\ (Av. Beira Mar s/n, 83255-000 Pontal do Paraná, PR, Brazil) \\ ${ }^{2}$ Instituto Oceanográfico da Universidade de São Paulo \\ (Praça do Oceanográfico 191, 05508-120 São Paulo, SP, Brazil)
}

\begin{abstract}
A B S T R A C T
A worldwide modeling effort has been proposed by the LOICZ (Land-Ocean Interactions in the Coastal Zone) Program to foster the acquisition of intercomparable data on land-ocean fluxes in estuaries and continental shelf ecosystems from all continental margins. As part of the South American component of this initiative, we present flux estimates of water, salt, dissolved inorganic phosphorus (DIP), dissolved inorganic nitrogen (DIN) and plankton for the estuarine system of Paranaguá Bay, southern Brazil, based on the LOICZ modeling approach and local data obtained during the 1990's. This system is strongly influenced by a seasonal meteorological cycle, represented by the rainy/summer and dry/winter periods. Semi-diurnal tides of up to the $2.7-\mathrm{m}$ range are responsible for the short time-scale dynamics. The model indicated a potential water export to the adjacent coast of up to $7 \times 10^{6} \mathrm{~m}^{3} \mathrm{~d}^{-1}$ in the dry season, and $28 \times 10^{6} \mathrm{~m}^{3} \mathrm{~d}^{-1}$ during the rainy season. The system exhibits seasonal and spatial variations in DIP and DIN fluxes. $\Delta$ DIP amounted to $+2.3 \mathrm{x}$ $10^{6} \mathrm{~mol} \mathrm{P} \mathrm{yr}^{-1}$ and $\Delta \mathrm{DIN}$ to $-2.7 \times 10^{6} \mathrm{~mol} \mathrm{~N} \mathrm{yr}^{-1}$, suggesting that net production of phosphate and consumption of inorganic nitrogen predominate throughout in the system. Fluxes and therefore export of DIN and eespecially of DIP are higher in the rainy season. Stoichiometric estimates based on the C:N:P ratios of the reacting particulate organic matter (mangrove and plankton detritus) suggest that net denitrification predominates all over the bay, with values between -24.3 and $-10.6 \mathrm{x}$ $10^{6} \mathrm{~mol} \mathrm{~N}$ year ${ }^{-1}$. Estimated seaward outflows had little effect upon the fate of the phyto- and zooplankton biomass in different sectors of the bay. This is exemplified by the low net export of algal production from the upper to the middle sectors of the estuary.
\end{abstract}

\section{R ESUMO}

Um esforço global de modelagem foi proposto pelo Programa LOICZ (Land-Ocean Interactions in the Coastal Zone) para promover a aquisição de dados comparáveis sobre fluxos continente-oceano em ecossistemas estuarinos e de plataforma em todos os continentes. Como parte do componente sulamericano desta iniciativa, apresentamos neste trabalho estimativas de fluxo de água, sal, fósforo inorgânico dissolvido (DIP), nitrogênio inorgânico dissolvido (DIN) e plâncton para o sistema estuarino da Baía de Paranaguá, obtidas a partir da aplicação de modelos sugeridos pelo programa LOICZ. Este sistema é fortemente influenciado por um ciclo meteorológico sazonal, representado pelos períodos chuvosos de verão e secos de inverno. As marés semidiurnas, com variação de até 2,7 m, são responsáveis pela dinâmica estuarina de curta escala temporal. Nossos resultados indicam uma exportação potencial de água para a área costeira adjacente de até $7 \times 10^{6} \mathrm{~m}^{3} \mathrm{~d}^{-1}$ no período seco e mais de $28 \times 10^{6} \mathrm{~m}^{3} \mathrm{~d}^{-1}$ no período chuvoso. O sistema exibe variações sazonais e espaciais nos fluxos de DIP e DIN. O $\Delta$ DIP atingiu $+2.3 \times 10^{6} \mathrm{~mol} \mathrm{P}^{2} \mathrm{ano}^{-1} \mathrm{e}$ o $\Delta$ DIN to $-2.7 \times 10^{6} \mathrm{~mol} \mathrm{~N}^{-1} \mathrm{ano}^{-1}$, sugerindo que a produção líquida de fosfato e o consumo de nitrogênio inorgânico predominam em todo o sistema. Os fluxos e, portanto, a exportação de DIN e principalmente de DIP são altos no período chuvoso. Estimativas estequiométricas baseadas nas razões $\mathrm{C}: \mathrm{N}: \mathrm{P}$ da matéria orgânica particulada reativa (detritos de origem planctônica e do manguezal) sugerem que o processo de denitrificação predomina em toda a baía, com valores entre -24.3 e $-10.6 \times 10^{6} \mathrm{~mol} \mathrm{~N} \mathrm{ano}^{-1}$. Os fluxos estimados em direção à área costeira adjacente tiveram pouco efeito sobre o destino da biomassa do fito- e zooplâncton nos diferentes setores da baía.

Descriptors: Mass balance, DIN and DIP budgets, Plankton dynamics, Paranaguá Bay, Brazil. Descritores: Balanço de massa, Fluxos de nitrogênio e fósforo dissolvidos, Dinâmica do plâncton, Baía de Paranaguá, Brasil.

$\overline{\text { Contr. No. } 870}$ do Inst. oceanogr. da Usp. 


\section{INTRODUCTION}

Estuaries are dynamic systems in which biological populations fluctuate according to natural cycles. Water quality also varies, particularly as seasonal and annual climatic patterns change. In these systems tracking environmental changes can be challenging, and distinguishing impacts caused by human actions from natural variations can be even more difficult. The transport and biogeochemical cycling of carbon (C), nitrogen $(\mathrm{N})$ and phosphorous $(\mathrm{P})$ in coastal zones may be altered by human activities leading to nutrient enrichment, such as sewage runoff, hydrological modifications, and increasing atmospheric carbon dioxide (Wollast, 1993). Environmental changes in the natural circulation of the above elements and their implications for the functioning of estuarine systems must be investigated within a temporal and spatial context, taking into account flux rates between continental and adjacent coastal systems.

Paranaguá Bay (Fig. 1), located in Paraná State (Southern Brazil), is one of the largest estuarine systems of the Southwestern Atlantic $\left(c a .600 \mathrm{~km}^{2}\right.$ of total water surface) and includes a coastal plain area, mangroves, salt marshes and the Atlantic rainforest ecosystem. Conservation units established under federal and state regulations protect a large proportion of the area. Around 19\% of the remnants of the Brazilian Atlantic rainforest are situated there. The unique ecological value of the Atlantic rainforest has been fully recognized worldwide, since the area became part of the United Nations Biosphere Reserve list in 1991.

Human occupation is concentrated mainly on the southern margin of the Bay, with a density of 200 inhabitants per square kilometer. On the northern margin, densities of 2 inhabitants per square kilometer are common. The population growth rate is less than $3 \%$ per year and has actually decreased in recent years. Major environmental impacts on the Bay are related to port activities (dredging, shipping, litter disposal, transport of non-indigenous species in commercial vessels) and agricultural activities, responsible for the release of $800 \mathrm{~kg}$ of pesticides per year (IPARDES, 1989). Other human activities, such as unruly urban occupation, timber extraction from forests, and cattle raising, lead to soil degradation, thus contributing to the sediment load to the bay (Andrigueto-Filho, 1993). Sewage from the main urban areas, especially Paranaguá, may represent a significant source of water pollution. All these impacts may, to some extent, affect the dynamics of the chemical elements in the water column of the estuarine system.

This study is the first stage of a broader research program which aims to investigate the processes of production, recycling and sinking routes of the biogenic matter in relation to the physical and biological environment in the Paranaguá Bay estuarine system. This paper specifically attempts to model the land-ocean fluxes of $\mathrm{C}, \mathrm{N}$ and $\mathrm{P}$ in Paranaguá Bay under the LOICZ (Land-Ocean Interaction in the Coastal Zone project) box-model approach and definitions (Gordon et al., 1996). This model is a useful tool for understanding the natural variation of the target elements in estuarine systems and for predicting possible environmental changes due to anthropogenic impacts. This approach also allows an inter-comparison of Paranaguá Bay with other estuaries around the globe, to which the same methodology has been applied.

\section{Material ANd Methods}

The box-model approach of Gordon et al. (1996) calls for the input of quantitative data on stocks and the process rates of the target properties.

The hydrographic budget is used to describe the inputs and outputs of materials, such as salt, contained in the water. Materials which enter or leave the system in water without undergoing net transformations within the system, are said to exhibit "conservative behavior." In this study, the dissolved inorganic forms of phosphorus and nitrogen, here termed DIP and DIN, are used to establish the nutrient budgets. These nutrient budgets include water flow and mixing, as defined by the water and salt budgets, and an additional term that describes net uptake or release of these nutrients within the system. Their fluxes are termed "nonconservative fluxes", because the nutrients are not conserved in the same proportion as the fluxes of water and salt.

Equation (1) defines the role of any particular budgeted system as a net source or sink for any particular material (Gordon et al., 1996):

$$
\Delta \mathrm{Y}=\mathrm{VdY} / \mathrm{dt}+\mathrm{YdV} / \mathrm{dt}-\Sigma \mathrm{V}_{\text {in }} \mathrm{Y}_{\text {in }}+\Sigma \mathrm{V}_{\text {out }} \mathrm{Y}_{\text {out }}
$$

The nonconservative flux of DIP can be used as an approximation of net uptake of phosphorus into organic matter during primary production or release from organic matter by decomposition or oxidation. The DIP flux is used as a proxy to estimate the carbon flux by applying a scaling ratio (typically a molar C:P ratio of 106:1 representing the so-called Redfield Ratio). This ratio was originally conceived for ocean waters, but LOICZ models use it as a reference to coastal waters as well (Gordon et al., 1996). Therefore, net ecosystem metabolism $(\mathrm{NEM}=[p-r])$ may be estimated from $\triangle \mathrm{DIP}$ and the C:P ratio of the reacting organic matter as follows (Gordon et al., 1996):

$$
(p-r)=-\Delta D I P \times(C: P) \text { part }
$$


Nitrogen fixation and denitrification are important metabolic processes in coastal systems and may account for most of the observed nonconservative flux of DIN. Thus, calculations derived from the budgets use $\triangle \mathrm{DIP}$ as a proxy to calculate how much net carbon uptake or release has occurred, scale this to expected nitrogen flux (typically using the Redfield $\mathrm{N}: \mathrm{P}$ ratio of 16:1), and then use the diference between the observed DIN flux ( $\Delta$ DINobs) and the expected flux ( $\triangle \mathrm{DINexp})$ from the decomposition of organic particles to estimate the net nitrogen fixation and denitrification, according to the relationship (Gordon et al., 1996):

$($ nfix-denit $)=\Delta$ DINobs $-\Delta$ DINexp $=\Delta$ DINobs $-\Delta \mathrm{DIP}$ $\times(\mathrm{N}: \mathrm{P})$ part

The following sections describe baseline information acquired from the literature or derived from our own observations and estimates. Because the availability and cycling of carbon, nitrogen and phosphorus in estuarine systems are strongly related to transport processes (sinking, advection, water input from external sources, etc) our first modeling procedure covers physical data and fluxes. Thereafter, the chemical budgets for $\mathrm{N}$ and $\mathrm{P}$ are presented and their implications for the ecosystem metabolism of different sectors of the estuarine system are discussed. Finally, input variables and fluxes in the planktonic compartment are dealt with, as biological processes affect $\mathrm{C}, \mathrm{N}$ and $\mathrm{P}$ dynamics in the water column.

\section{Physical Description and Input Data}

The estuarine system of Paranaguá Bay $\left(\sim 25^{\circ} 30^{\prime} \mathrm{S} \& 48^{\circ} 30^{\prime} \mathrm{W}\right)$ is a micro-mesotidal barrier estuary with a water surface area of about $600 \mathrm{~km}^{2}$. It is formed of two major embayments: 1) Laranjeiras Bay, $30 \mathrm{~km}$ long and $13 \mathrm{~km}$ wide, lying in the northsouth direction; and 2) Paranaguá Bay itself, $50 \mathrm{~km}$ long and $7 \mathrm{~km}$ wide, on an east-west axis (Fig. 1).

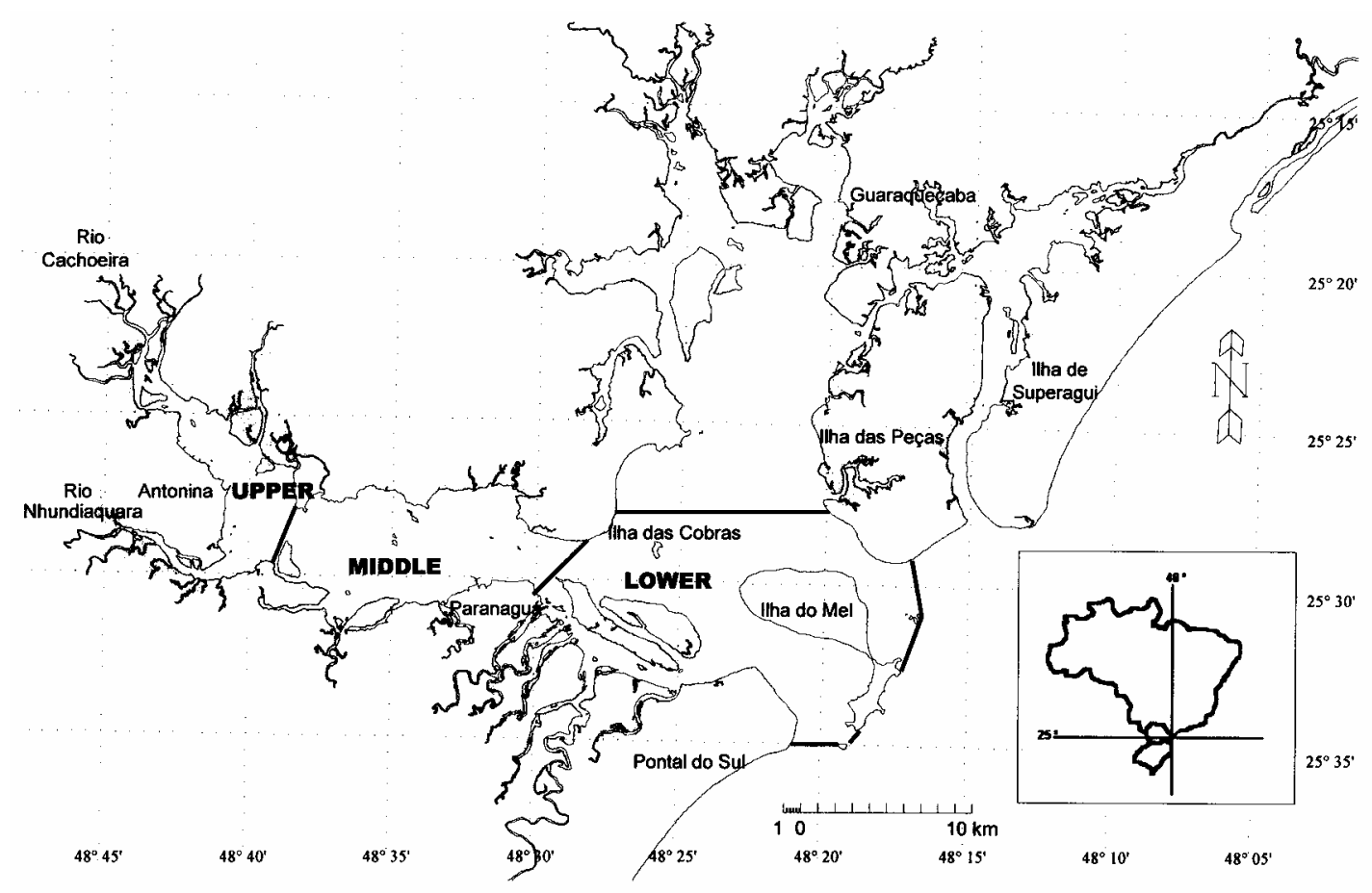

Fig. 1. The Estuarine Complex of Paranaguá Bay. Upper, middle and lower sectors are shown (see text for details). 
This study focusses on Paranaguá Bay properly, with a water surface area of $330 \mathrm{~km}^{2}$ and a water volume of $1.8 \times 10^{9} \mathrm{~m}^{3}$. This east-west branch has a main depth of $5.4 \mathrm{~m}$, and a maximum of $33 \mathrm{~m}$. The tidal prism is $\sim 0.58 \mathrm{~km}^{3}$ with a tidal intrusion of $\sim 7.7$ $\mathrm{km}$ and a flow time of $\sim 3$ days (with seasonal/tidal variations). The horizontal seaward gradient of mean salinity (expressed in practical salinity units; UNESCO, 1985) ranges from 12-29 (summer) to 2034 (winter), with maximum gradients of $0-35$ (summer) and 3-35 (winter). Mean water temperature ranges from 23 to $30^{\circ} \mathrm{C}$ (summer) and from 18 to $25^{\circ} \mathrm{C}$ (winter). Maximum observed currents approach 0.85 $\mathrm{m} \mathrm{s}^{-1}$ (ebb) and $1.10 \mathrm{~ms}^{-1}$ (flood). The basin catchment area is around $1,918 \mathrm{~km}^{2}$, with river gradients from $5: 1$ to $15: 1$. The mean annual river fresh water input is up to $200 \mathrm{~m}^{3} \mathrm{~s}^{-1}$. The area presents a mean annual rainfall of $\sim 2,500 \mathrm{~mm}$ (maximum of 5,300 $\mathrm{mm}$ ), with maximum daily rainfall of up to $230 \mathrm{~mm}$. A summary of the above-mentioned features is given in Table 1.

Paranaguá Bay is classified as a partially mixed estuary (type b) with lateral inhomogeneities, but the system may be seen as fitting homogeneous or even stratified conditions, depending on the season and/or tidal stage (Lana et al., 2000). In accordance with the salinity gradients, Lana et al. (2000) defined three areas for the Paranaguá branch (Fig. 1): (i) the upper, meso-tidal, oligo- to mesohaline sector; (ii) the middle (or central), micro- to meso-tidal, oligo- to polyhaline sector; and (iii) the lower, micro to mesotidal, poly- to euhaline sector. The lower section was modeled in view of the absence of any net exchange with the northward branch of the system, Laranjeiras Bay, which has an independent connection to the coast through the Superagüí channel in the middle-north section.

The seasonal variability in the area has to be considered when computing flux rates because of differences in salinity and temperature gradients, and in fresh water inputs, among other factors (Knoppers et al., 1987). During the dry season fresh water input is about $30 \%$ lower than the annual mean, increasing by up to $170 \%$ of mean values during the rainy season. Contrasting circulation patterns are generally found in rainy and dry seasons (Marone et al., 1995). For this reason, fluxes for the three sectors will be treated separately here for the two periods.

Spring tidal ranges run from $1.7 \mathrm{~m}$ at the mouth to $2.7 \mathrm{~m}$ in the upper sector of the bay. The tidal regime is mainly semidiurnal, with diurnal inequalities. Tidal constituents show strong non-linear interactions. Tidal ranges run typically from microtidal during neap tides to meso-tidal during spring tides. Storm surge effects may increase tidal heights by up to $80 \mathrm{~cm}$ (Marone \& Camargo, 1994). Wave action, mainly from the southeast, is only significant at the bay mouth, but easterly winds may produce locally generated surface waves. Mean significant wave heights at the mouth are around $0.5 \mathrm{~m}$, with periods of around 3-7 s, but maximum wave heights can reach 2 or $3 \mathrm{~m}$ in stormy periods. Table 2 contains the main tidal characteristics for the different compartments (Marone \& Camargo, 1994).

Table 1. Physical characteristics of upper, middle and lower sections of Paranaguá Bay, as depicted in Figure 1.

\begin{tabular}{|c|c|c|c|c|c|c|c|c|}
\hline Sector & $\begin{array}{c}\text { Section } \\
\text { Area } \\
\left(10^{3} \mathrm{~m}^{2}\right)\end{array}$ & $\begin{array}{l}\text { Area } \\
\left(10^{6} \mathrm{~m}^{2}\right)\end{array}$ & $\begin{array}{l}\text { Mean } \\
\text { Depth } \\
\text { (m) }\end{array}$ & $\begin{array}{l}\text { Water } \\
\text { Volume } \\
\left(10^{6} \mathrm{~m}^{3}\right)\end{array}$ & $\begin{array}{r}\mathrm{Ru} \\
\left(10^{6}\right. \\
\text { Rain }\end{array}$ & $\begin{array}{l}\text { ff } \\
/ / d) \\
\text { Dry }\end{array}$ & $\begin{array}{c}\text { Tidal } \\
\text { Discharge } \\
\left(\mathrm{m}^{3} / \mathrm{s}\right)\end{array}$ & $\begin{array}{c}\text { Tidal } \\
\text { Prism } \\
\left(10^{6} \mathrm{~m}^{3}\right)\end{array}$ \\
\hline Upper & 9 & 50 & 1.9 & 95 & 10 & 3 & 5331 & 119 \\
\hline Middle & 50 & 93 & 4.3 & 400 & 7 & 2 & 7885 & 176 \\
\hline Lower & 130 & 187 & 7.0 & 1309 & 4 & 1 & 12724 & 284 \\
\hline
\end{tabular}

Table 2. Tidal characteristics for the main sectors of Paranaguá Bay.

\begin{tabular}{|c|c|c|c|c|c|c|c|c|c|}
\hline Sector & $\begin{array}{c}\text { Out of } \\
\text { Spring } \\
\text { high }\end{array}$ & $\begin{array}{l}\text { Phase } \\
\text { (min) } \\
\text { low }\end{array}$ & $\begin{array}{l}\text { Out of } \\
\text { Neap } \\
\text { high }\end{array}$ & $\begin{array}{l}\text { Phase } \\
\text { min) } \\
\text { low }\end{array}$ & $\begin{array}{l}\text { Ebb } \\
\text { Time } \\
\text { (h) }\end{array}$ & $\begin{array}{c}\text { Flood } \\
\text { Time } \\
\text { (h) }\end{array}$ & $\begin{array}{c}\text { Range } \\
\text { Spring } \\
\text { (m) }\end{array}$ & $\begin{array}{c}\text { Range } \\
\text { Neap } \\
(\mathrm{m})\end{array}$ & $\begin{array}{c}\text { Mean } \\
\text { Range } \\
(\mathrm{m})\end{array}$ \\
\hline Upper & - & - & - & - & 6.8 & 5.5 & $1.74 \mathrm{~m}$ & $1.30 \mathrm{~m}$ & $1.52 \mathrm{~m}$ \\
\hline Middle & 88 & 68 & 106 & 93 & 7.5 & 4.8 & $2.09 \mathrm{~m}$ & $1.70 \mathrm{~m}$ & $1.89 \mathrm{~m}$ \\
\hline Lower & 100 & 110 & 132 & 151 & 8.1 & 4.2 & $2.74 \mathrm{~m}$ & $2.02 \mathrm{~m}$ & $2.38 \mathrm{~m}$ \\
\hline
\end{tabular}


The groundwater lens appears near the surface in the plain areas and is exposed during the rainy season (Lana et al., 2000). Although no complete evaluation of the groundwater contribution has been made for the system, evidence has shown that this freshwater source may contribute significantly to the total discharge (Marone et al., 1997). A single tidal creek, with depths below the groundwater lens, contributes to the system with a fresh water input corresponding to roughly $30 \%$ of the rest currents values. Considering the catchment area of this tidal creek and the total catchment area of the coastal plain system, groundwater fluxes probably represent up to $10 \%$ of the surface freshwater runoff.

No direct measurements of water evaporation or evapo-transpiration rates were undertaken for Paranaguá Bay. Estimates obtained from similar nearby ecosystems indicate a mean annual evaporation rate of about $6 \mathrm{~mm} \mathrm{day}^{-1}$ (Lana et al., 2000).

Table 3 shows average current values for water masses crossing the sections separating the upper from the middle sector, the middle from the lower sector and, finally, the lower area from the shelf. The data are tabulated for rainy and dry seasons and are all positive, indicating water export in all sections. Rest currents are $0.03 \mathrm{~ms}^{-1}$ for all sectors during the rainy season, but $0.01 \mathrm{~ms}^{-1}$ during the dry season, except for the inner to middle, where they are of up to $0.02 \mathrm{~ms}^{-1}$. The fresh water fluxes estimated for rainy and dry seasons are given in Table 4.

Table 3. Cross-section mean current velocities at sector boundaries.

\begin{tabular}{ccc}
\hline \hline $\begin{array}{c}\text { Sector } \\
\text { (cross section) }\end{array}$ & $\begin{array}{c}\text { Mean } \\
\text { Current } \\
\text { (rainy-m/s) }\end{array}$ & $\begin{array}{c}\text { Mean } \\
\text { Current } \\
\text { (dry-m/s) }\end{array}$ \\
\hline Upper to Middle & $0.18 \mathrm{~m} / \mathrm{s}$ & $0.37 \mathrm{~m} / \mathrm{s}$ \\
Middle to Lower & $0.29 \mathrm{~m} / \mathrm{s}$ & $0.33 \mathrm{~m} / \mathrm{s}$ \\
Lower to the coast & $0.30 \mathrm{~m} / \mathrm{s}$ & $0.34 \mathrm{~m} / \mathrm{s}$ \\
\hline
\end{tabular}

\section{Chemical Description and Input Data}

Earlier studies have shown that physical, chemical and biological properties in Paranaguá Bay are strongly dependent and controlled by climatic factors (rain and wind regime), which modify the intensity of tidal action (Knoppers et al., 1987; Brandini et al., 1988; Rebello \& Brandini, 1990; Marone \& Camargo, 1994; Machado et al., 1997).

A detailed description of the spatial and temporal dynamics of water column nutrients is available (Machado et al., 1997) and only a brief overview is given below. The nutrient environment and trophic status of Paranaguá Bay are the net result of interactions between hydrodynamic processes and different mechanisms of sink and supply of these constituents. Such processes include biological uptake, freshwater input associated with the rainfall regime, sediment-water interactions and sewage discharge from the city of Paranaguá. The highest values of chlorophyll $a$ and dissolved inorganic nutrients are found in the middle and upper regions of the bay, during the rainy period. The conservative behavior observed for silicate, and to a certain extent for nitrate, indicates that the continental drainage is the main source of these nutrients. On the other hand, the middle sector of the bay constitutes a sink for nitrate and a source for ammonium and nitrite. The N:P ratio shows spatial and temporal variability, with higher values in the upper bay during the rainy season, in association with an increased input from the continental drainage during this period. The predominance of N:P ratios (molar) below the classic Redfield value of 16:1 (Redfield, 1958) shows, however, that nitrogen potentially constitutes the most limiting nutrient in the bay, probably as a result of denitrification in surface sediments and adjacent bottom waters (Seitzinger, 1988).

Table 4. Fresh water estimates for rainy and dry seasons in Paranaguá Bay.

\begin{tabular}{ccccccc}
\hline \hline Sector & $\begin{array}{c}\text { Rain } \\
(\text { rainy }) \\
\left(\mathrm{m}^{3} / \text { day }\right)\end{array}$ & $\begin{array}{c}\text { Rain } \\
(\text { dry }) \\
\left(\mathrm{m}^{3} / \text { day }\right)\end{array}$ & $\begin{array}{c}\text { Groundwater } \\
(\text { rainy }) \\
\left(\mathrm{m}^{3} / \text { day }\right)\end{array}$ & $\begin{array}{c}\text { Groundwater } \\
(\text { dry }) \\
\left(\mathrm{m}^{3} / \text { day }\right)\end{array}$ & $\begin{array}{c}\text { Evapor. } \\
(\text { rainy }) \\
\left(\mathrm{m}^{3} / \text { day }\right)\end{array}$ & $\begin{array}{c}\text { Evapor. } \\
(\mathrm{dry}) \\
\left(\mathrm{m}^{3} / \mathrm{day}\right)\end{array}$ \\
\hline Upper & $0.29 \times 10^{6}$ & $0.10 \times 10^{6}$ & $0.576 \times 10^{6}$ & $0.2 \times 10^{6}$ & $0.25 \times 10^{6}$ & $0.17 \times 10^{6}$ \\
Middle & $0.99 \times 10^{6}$ & $0.35 \times 10^{6}$ & $0.576 \times 10^{6}$ & $0.2 \times 10^{6}$ & $0.82 \times 10^{6}$ & $0.58 \times 10^{6}$ \\
Lower & $2.17 \times 10^{6}$ & $0.77 \times 10^{6}$ & $0.576 \times 10^{6}$ & $0.2 \times 10^{6}$ & $1.79 \times 10^{6}$ & $1.28 \times 10^{6}$ \\
\hline
\end{tabular}


Suspended particulate matter in the entire bay ranges from 10 to $120 \mathrm{mg} \mathrm{l}^{-1}$ in summer (rainy season), values about $40 \%$ lower being observed in winter (dry season). The highest values are found in the upper sector (Lana et al., 2000). The highest values of particulate organic carbon:chlorophyll $a$ ratios (POC:Chl $a$ ) occur in autumn and winter. This pattern suggests a temporal variation in the source of particulate organic matter to the pelagic compartment, with a relatively greater contribution of phytoplanktonic material (autochthonous production) during summer. The trophic state of Paranaguá Bay varies seasonally and spatially, from almost oligotrophic in winter in the lower sector, to eutrophic during summer in the middle and upper sectors of the Bay. There are still no data available on the total amount of allochthonous carbon entering the system. Flux rates of organic material and dissolved nutrients from mangroves are still unknown. Although there are uncertainties regarding the lateral deposition of organic material in shallow, sheltered areas, rough estimates suggest that the anthropogenic input has increased $24 \%$ during the past 15 years. Nevertheless, no marked variation in the trophic state has occurred during this period. Probably the short residence time hampers the eutrophication process of the system.

The DIP and DIN $\left(\mathrm{NH}_{4}^{+}+\mathrm{NO}_{3}^{-}+\mathrm{NO}_{2}^{-}\right)$ budgets are based on data obtained between June 1994 and July 1995 (Machado et al., 1997). In this study, samples of surface and bottom water were collected monthly at nine stations, three in each sector of the system. The values used in the budget calculations presented here are the seasonal average concentrations of DIN and DIP of the three stations for each sector. The DIN and DIP concentrations in rivers were obtained from short-term sampling in winter/1997 and summer/1998. There are no data available for dissolved organic nutrients.

Moreover, budgets include estimates of the anthropogenic loading of DIP and DIN, that is, of sewage discharge from the cities of Antonina (17,070 inhabitants) and Paranaguá (107,675 inhabitants) to the upper and middle sectors, respectively. A broad range of effluent values related to domestic, agriculture and cattle raising sources is reported by several studies (FEEMA, 1987; Costa et al., 1999; San Diego-McGlone et al., 1999; Camacho-Ibar et al., 2002). We have assumed an estimate for per capita production of $80 \mathrm{mmol} \mathrm{P}$ and $930 \mathrm{mmol} \mathrm{N}$ person $^{-1}$ day $^{-1}$ and that approximately $70 \%$ of the population contributes effectively to the sewage disposal (Machado et al., 1997).

\section{Biological Description and Input Data}

Relatively few studies on phyto- and zooplankton associations have been carried out in
Paranaguá Bay so far. The main approach of such investigations has been essentially descriptive and usually at spatial and temporal scales not sufficiently accurate to provide a more detailed picture of the intrinsic variability of these associations.

The composition and numerical density of pelagic microalgae were analyzed during two annual periods, viz. Jul 83-Jun 84 (at 1 sampling site in the middle section of the Bay; Brandini, 1985a) and JanDec 86 (at 2 stations representative of the lower and middle areas; Brandini \& Thamm, 1994). These studies have shown the numerical importance of centric diatoms as compared to that of other groups, with Skeletonema costatum as the dominant algal species. Rezende (1995) performed daily sampling of phytoplankton during two monthly periods in summer and winter, at a fixed station under the influence of coastal waters. Her results suggested that meteorological forcing related to mesoscale processes is a key environmental factor controlling phytoplankton populations in the lower region of the bay.

Phytoplankton biomass has been more extensively evaluated in the lower and middle bay, with typical average values of around 2.0 and $6.0 \mathrm{mg}$ Chl- $a \mathrm{~m}^{-3}$, respectively. The available chlorophyll- $a$ data cover at least part of the interannual variability, because several measurements have been performed in euhaline to mesohaline areas since the early 1980's, at monthly or biweekly intervals (e.g., Brandini et al., 1988; Lopes, 1997; Machado et al., 1997). Temporal and spatial coverage of data on phytoplankton primary production is not as consistent as that for phytoplankton biomass. Photosynthetic parameters have been estimated by the oxygen method at some stations, though excluding the upper sector of the bay (Brandini, 1985b; Brandini \& Thamm, 1994).

Montú \& Cordeiro (1988) have shown the numerical dominance of pelagic copepods relative to other holo- and meroplanktonic taxa, as observed in most estuaries around the world. Zooplankton distributional patterns are closely linked to the local salinity (S) gradient, thus defining four basic holoplanktonic associations (Lopes et al., 1998): (i) the estuarine group $(\mathrm{S}<15)$, (ii) the estuarine-marine group $(15<\mathrm{S}<25)$, (iii) the marine-euryhaline group $(\mathrm{S}>25)$, and (iv) the stenohaline marine biota $(\mathrm{S}>32)$, which penetrates the lower bay especially during spring tides in the dry season.

Although the available data are sufficient for the purpose of identifying the above-mentioned associations, our current knowledge of the ecological processes associated with the zooplankton biota is severely limited by poor sampling strategies on both spatial and time scales, and also by an excessive emphasis on descriptive analysis of distributional patterns, usually dissociated from a more process- 
orientated approach. A first attempt to analyze timeseries data of zooplankton abundance and grazing rates was undertaken by Lopes (1997), but such extended information is restricted to the lower sector of the bay.

Because of the above-mentioned limitations, in some cases planktonic stocks and fluxes have been estimated by employing conversion factors available in the literature. Phytoplankton carbon has been derived from direct chlorophyll- $a$ measurements considering an average $\mathrm{C}: \mathrm{Chl} a$ ratio of 52, typical for estuarine systems (Dam \& Peterson, 1993). Since primary production rates have been obtained on just a few occasions and sites (Brandini, 1985b; Brandini \& Thamm, 1994), we have chosen to apply a generalized growth rate of 1.6, consistent with actual rates obtained in other systems harboring the same dominant algae as in Paranaguá Bay (Jørgensen, 1994). Phytoplankton respiration has been estimated from data obtained by Teixeira et al. (1969) from the contiguous estuarine system of Cananéia. Average algal R:P ratios of 0.261 and 0.274 have been calculated for the rainy and dry seasons, respectively. Zooplankton standing-stocks represent crude estimates obtained from the conversion of numerical densities into carbon biomass per unit volume. The average body length of several species and their developmental stages have been obtained from direct observations or from the literature (e.g., Björnberg, 1972; 1981). Linear or power equations relating length to weight have been applied and, where necessary, the resulting weight estimates have been converted into carbon using the empirical equations of Wiebe et al. (1975). Length-to-weight relationships have been taken from several sources, including Paffenhöfer (1976), Feigenbaum (1979), Pearre (1982), Deibel (1985; 1988), Chisholm \& Roff (1990) and Webber \& Roff (1995). Zooplankton respiration rates have been considered equivalent to $10 \%$ of the standing-stock on a daily basis (Day et al., 1973), while excretion rates have been estimated from carbon biomass and temperature data, in accordance with Ikeda (1985). All estimated stocks and fluxes related to zooplankton associations are for the mesozooplankton size class (organisms $>200 \mu \mathrm{m}$ ).

\section{Results And Discussion}

In the following figures, we present different box models for water, salt, and non-conservative properties, including nutrients and plankton standingstock, calculated as in Gordon et al. (1996). Unknown data (?), estimated values obtained from the literature (L), and those with a great degree of uncertainty (!), are indicated in the box model figures accordingly.

\section{Physical Fluxes}

The water balance differs significantly between rainy (summer) and dry (winter) seasons. Fluxes are reduced by around 4 times in the latter (Fig. 2). Evaporation and rain contribution are very similar and thus relatively unimportant for the total water balance (Table 4). Water flux depends mainly on river runoff, but recent preliminary estimates of groundwater contribution indicate values that may be of the same order of magnitude as the rainfall contribution. The possible contribution of dissolved chemical components, normally high in a groundwater lens, is another point to be considered in the future. Residual fluxes increase from the upper to the lower part of the bay.

The results suggest that the East-West branch of the estuarine system releases water to the coastal zone with values ranging from $7 \times 10^{6} \mathrm{~m}^{3} / \mathrm{d}$ in the dry season to $28 \times 10^{6} \mathrm{~m}^{3} / \mathrm{d}$ during the rainy season. The system shows a net import of salt during dry periods, and an equivalent export during rainy seasons. These conclusions have been obtained from the balance calculation, considering a non-stationary process between summer and winter conditions. Seasonal changes are, therefore, a major source of variability in this system due to the differences in river runoff between rainy and dry periods. Because circulation is also driven by tidal forcing, long-term (seasonal) time series are required for an accurate calculation of residual and mixing fluxes.

\section{Chemical Fluxes - Budgets of Nonconservative Materials $\mathrm{P}$ and $\mathrm{N}$ balances}

Nonconservative fluxes of DIP (Fig. 3 and Tables 5 and 6) are positive in all three sectors of Paranaguá Bay during the rainy period, suggesting a net production of DIP within the system in this season. During the dry period, only the lower sector had positive DIP fluxes, while a net sink was observed in the upper and middle sectors. On an annual basis and over the whole system, $\triangle \mathrm{DIP}$ amounts to $+2.3 \mathrm{x}$ $10^{6} \mathrm{~mol} \mathrm{P} \mathrm{yr}^{-1}\left(=+7 \mathrm{mmol} \mathrm{P} \mathrm{m}^{-2} \mathrm{yr}^{-1}\right)$. If phosphate desorption from sediments does not contribute substantially to $\triangle \mathrm{DIP}$, then this DIP production is probably the result of net organic matter oxidation. Sewage discharge amounts to approximately $0.9 \times 10^{6}$ mol $\mathrm{P} \mathrm{yr}^{-1}$. This accounts for $39 \%$ of the observed flux of DIP. The Paranaguá Port constitutes an additional anthropogenic, non-quantified, source of Pfertilizer residues from loading and unloading operations. 


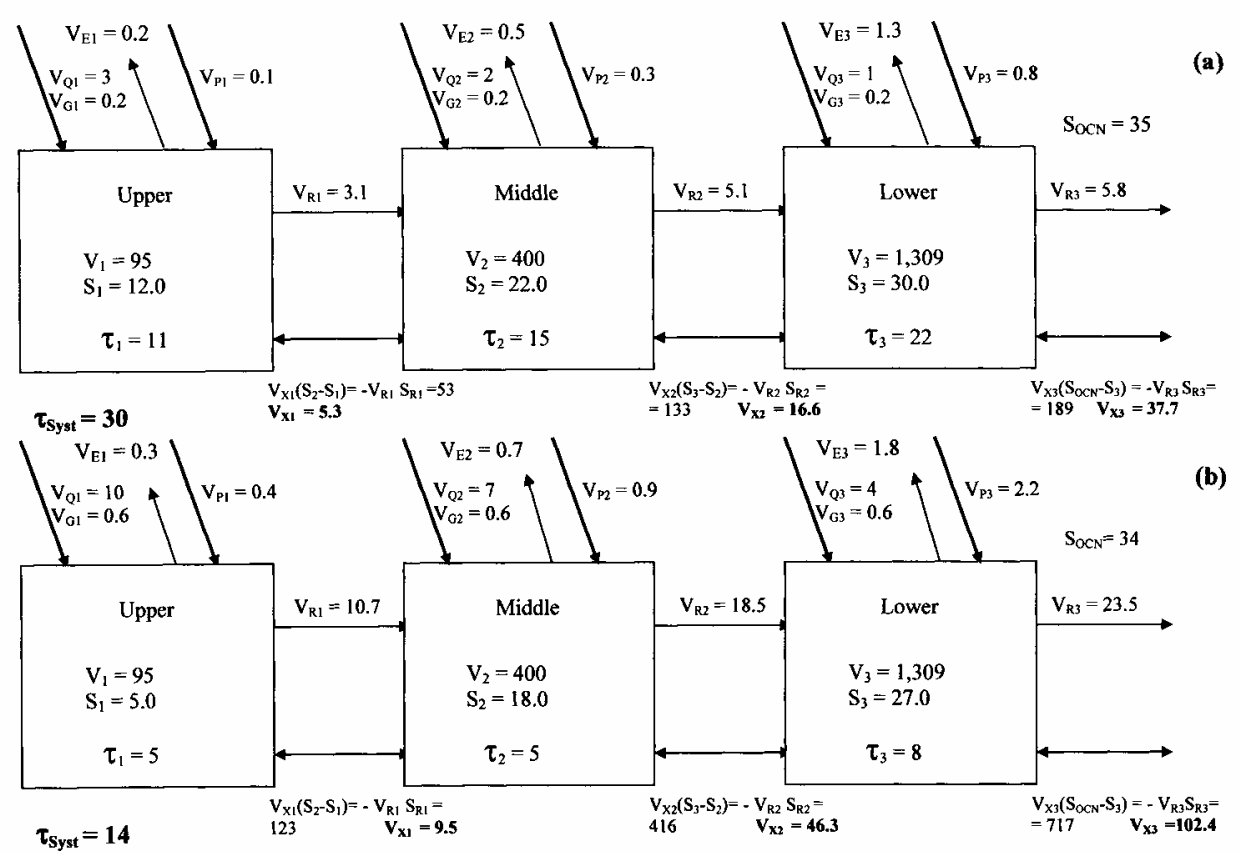

Fig. 2. Salt and water budgets for Paranaguá Bay in dry (a) and rainy (b) seasons
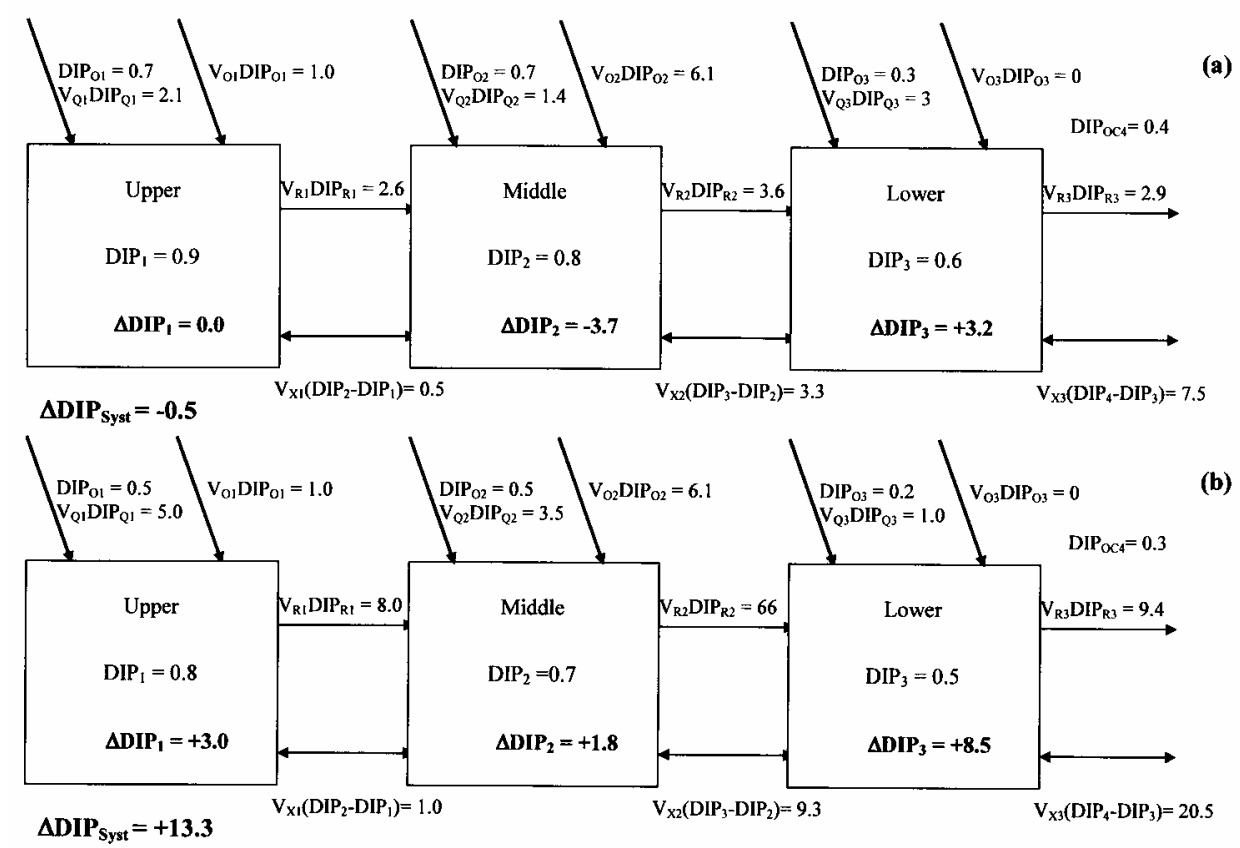

Fig. 3. Steady-state DIP budget for Paranaguá Bay in dry (a) and rainy (b) seasons. 
The picture is somewhat more complicated for DIN (Fig. 4 and Tables 5 and 6). The upper sector appears to be a net sink of DIN in both periods, especially in the rainy season; the middle sector shows a net uptake in the dry period and a net production of DIN in the rainy season. Nonconservative fluxes of DIN are positive in the lower sector of the bay, in both seasons, though principally in the rainy months. On an annual basis, over the entire estuary, $\triangle \mathrm{DIN}$ is $-2.7 \mathrm{x}$ $10^{6} \mathrm{~mol} \mathrm{~N} \mathrm{yr}^{-1}\left(=-8 \mathrm{mmol} \mathrm{N} \mathrm{m}^{-2}\right.$ year $\left.^{-1}\right)$, suggesting that net consumption of DIN predominates thoughout the system.

Differences in import and export of nitrogen and phosphorous were identified and these may be related to differences in the internal biogeochemical processes that trap and release these materials. Although the DIP and DIN concentrations in all three sectors of the system do not present significant differences between rainy and dry seasons, fluxes are much higher in the rainy season, especially for DIN. This is reflected by the export of DIN and DIP to the adjacent coastal area: the export of DIN and DIP is higher by a factor of 3.5 and 2.7 , respectively, in the rainy as compared to the dry season. Moreover, during the dry period, about $45 \%$ of the nitrogen flowing into the estuary from river basins and sewage sources is lost to biogeochemical sinks, while only about $5 \%$ of the phosphorous input is so lost.

\section{Biological Fluxes - Planktonic Compartment}

Despite the uncertainties associated with the use of several of the conversion factors and the limitations caused by lack of data on many key processes, the result of our preliminary exercise (Fig. 5) provides some useful information.

Advection accounted for the loss of only 0.2 to $14 \%$ of the total phytoplankton production (generally $<5 \%$ ), with a decreasing influence from the upper to the lower bay and an obvious minor contribution during the dry season. Mesozooplankton grazing also seems to play a relatively minor role, with about $2.0 \%$ of the primary production being consumed in one day. Lopes (1997) obtained a similar zooplankton grazing impact in terms of algal biomass. Thus, losses other than those estimated by us, including gravitational fluxes (sedimentation) and herbivory by other components of the estuarine ecosystem (microzooplankton, planktivorous fishes, benthic filter-feeders, etc) may possibly be of major

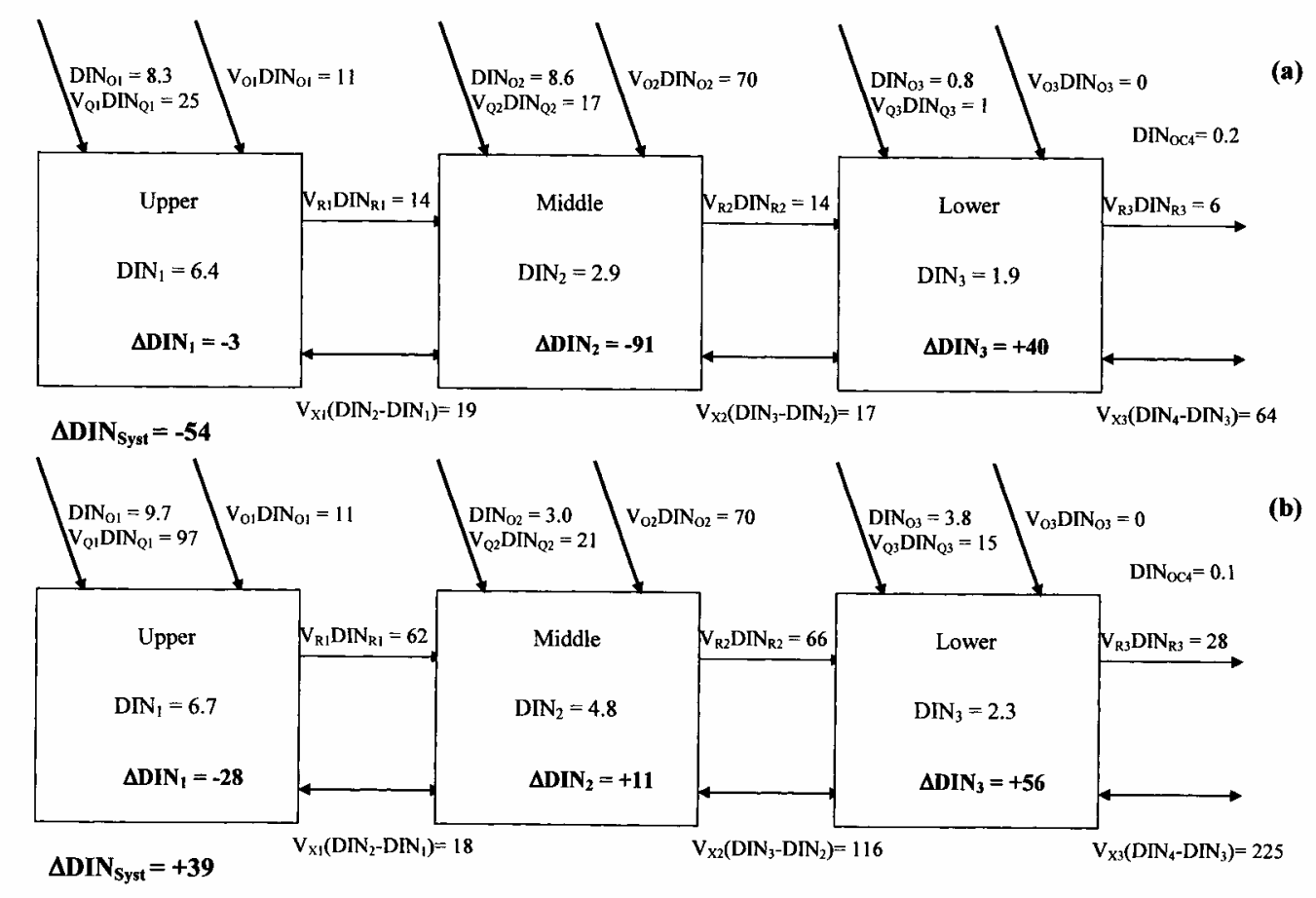

Fig. 4. Steady-state DIN budget for Paranaguá Bay in dry (a) and rainy (b) seasons. 


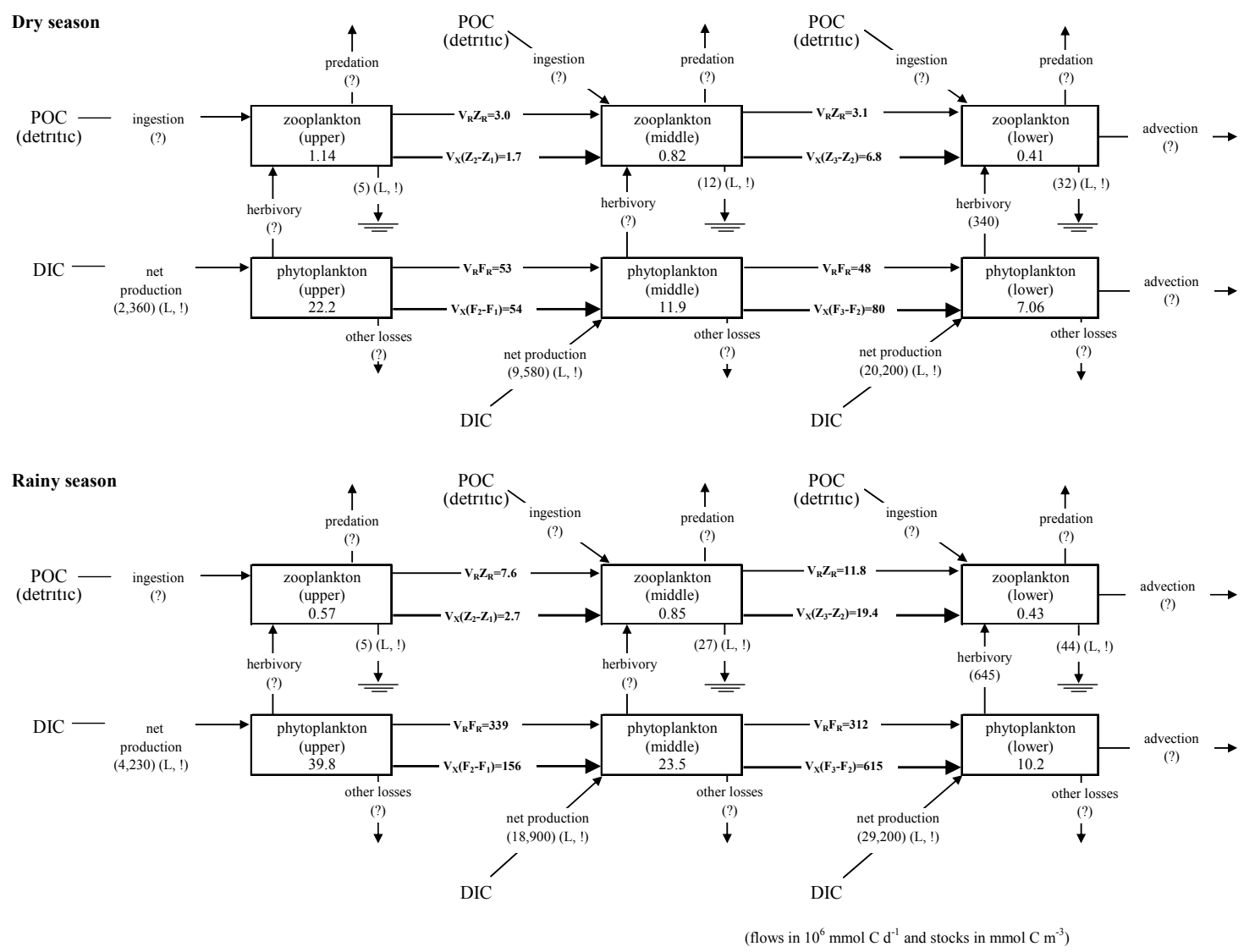

Fig. 5. Plankton box model for Paranaguá Bay in dry and rainy seasons.

importance. Further studies on process rates and more accurate estimates of standing-stocks are, therefore, needed for a better understanding of the pelagic ecosystem of Paranaguá Bay.

\section{Stoichiometry of System Metabolism}

The stoichiometric calculations of nitrogen fixation - denitrification (nfix - denit) presented in Tables 5 and 6 are derived from the differences between observed (obs) and expected (exp) values for $\triangle \mathrm{DIN}$ from the decomposition of organic particles, according to the relationship given in Gordon et al. (1996). However, independent estimates suggest that organic metabolism in this system is dominated by plankton and mangrove detritus (Brandini, 1985b; Machado et al., 1997). The expected values are, therefore, based on a range for $\mathrm{N}: \mathrm{P}_{\text {part }}$ covering both mangrove detritus $\left(\mathrm{N}: \mathrm{P}_{\text {part }} \approx 11: 1\right)$ and plankton
$\left(\mathrm{N}: \mathrm{P}_{\text {part }} \approx 16: 1\right)$. Net denitrification predominates all over the bay, with values of between -24.3 to $-10.6 \mathrm{x}$ $10^{6} \mathrm{~mol} \mathrm{~N} \mathrm{yr}^{-1}\left(=-0.07\right.$ to $\left.-0.03 \mathrm{~mol} \mathrm{~N} \cdot \mathrm{m}^{-2} \mathrm{yr}^{-1}\right)$. The exception is the middle sector of the bay during the rainy season, where nitrogen fixation exceeds denitrification. Although these rates are only rough estimates, they seem reasonable and are in the same range as those reported for other coastal systems (Nowicki et al., 1997; Kelly, 1998; Christian \& Thomas, 2000).

While none of the macronutrients appeared to be in short supply for plankton production, there was a greater excess of phosphorous than of nitrogen. Consequently, nitrogen comes closer to being a limiting nutrient than do other materials. Moreover, these results are in agreement with earlier studies, which reported $\mathrm{N}: \mathrm{P}$ ratios usually lower than the classical Redfield ratio, because of denitrification processes (Knoppers et al., 1987; Machado et al., 
1997). However, denitrification rates have not yet been directly measured for Paranaguá Bay. Other pathways might constitute important sinks for dissolved inorganic nitrogen. Kuypers et al. (2003) found evidence for bacteria (anammox bacteria) that anaerobically oxidize ammonium with nitrite to $\mathrm{N}_{2}$ in the world's largest anoxic basin, the Black Sea. Environments such as the middle and upper sectors of Paranaguá Bay, where ammonium and nitrite both occur in the presence of low oxygen concentrations, might be suitable habitats for anammox-like reactions (Zehrl \& Ward, 2002).

Net ecosystem metabolism $(\mathrm{NEM}=[p-r])$ has been estimated assuming that the reacting organic matter is dominated by plankton and mangrove detritus, with C:P ratios of about 106:1 and 1000:1 (Smith et al., 1997), respectively. On an annual scale,

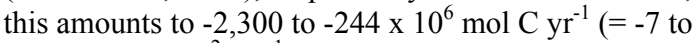
$\left.-0.7 \mathrm{~mol} \mathrm{C} \mathrm{m} \mathrm{mr}^{-1}\right)$ for the entire system. With mangroves dominating the net metabolism, the rates of (p-r) would seem to be excessively high. This suggests that the net reacting matter is plankton, thus, in some measure, contradicting the earlier studies cited above. However, the shift from low net autotrophy in dry periods to moderate net heterotrophy in rainy periods indicates that importation of organic matter is a key process in the functioning of the Bay. If our stoichiometric assumptions are valid, Paranaguá Bay is a net heterotrophic system throughout the annual cycle, with higher net metabolic rates during the warm, rainy season.

\section{Implications for Management Strategies}

Despite their preliminary nature, the present budget results may possibly provide support for the establishment of management strategies and actions with a view to the sustainable development of the Paranaguá Bay area. Because our results suggest that eutrophication processes and their consequences such as oxygen depletion tend to be more intense during the net heterotrophic rainy period, care should be taken to minimize the effect of the sewage load to the bay, especially at this latter time of the year. In addition the constant dredging activity needed for harbor operations, which removes more than two million cubic meters per year (Soares \& Marone, 1997) and causes resuspension of anoxic sediments, must be restricted to the low-flux dry period in order to reduce its environmental impact. Data on coupling mechanisms between the water column and the sediments are just beginning to be collected (although mostly for inorganic nutrients) and a much greater effort must be made to understand the interactions among the pelagic and benthic biota.

Another application of our budget estimates may be related to management strategies of exotic organisms potentially introduced from ballast water release or other shipping operations at the ports of Paranaguá and Antonina. The apparent low export of planktonic material to the coastal system indicates that invasive species might have a sufficiently long period of residence in the upper and middle sections of the bay as to allow their establishment, should they succeed in adapting to the new environment. These are only a few examples of possible applications of the LOICZ box models of Gordon et al. (1996) in a regional context, and we would encourage further studies in line with this approach in Paranaguá Bay and other estuarine systems in tropical and subtropical Brazil.

\section{ACKNOWLEDGEMENTS}

The authors wish to acknowledge the comments and suggestions provided by two anonymous reviewers. EM and RML both received financial support from the $\mathrm{CNPq}$ during the course of this study (Proc. 301006/2004-4 and 308055/2004-7, respectively).

\section{REFERENCES}

Björnberg, T. K. S. 1972. Developmental stages of some tropical and subtropical planktonic marine copepods. Stud. Fauna Cur. Other Carib. Is., 40:1-185.

Björnberg, T. K. S. 1981. Copepoda. In: Boltovskoy D (ed) Atlas del zooplancton del Atlántico Sudoccidental y métodos de trabajo com el zooplancton marino. Mar del Plata, INIDEP, p. 587-679.

Brandini, F. P. 1985a. Seasonal succession of the phytoplankton in the Bay of Paranaguá (Paraná State Brazil). Rev. Brasil. Biol., 45(4):687-694.

Brandini, F. P. 1985b. Ecological studies in the Bay of Paranaguá. I. Horizontal distribution and seasonal dynamics of the phytoplankton. Bolm Inst. oceanogr., S Paulo, 33:139-147.

Brandini, F. P. \& Thamm, C. A. C. 1994. Variações diárias e sazonais do fitoplâncton e parâmetros ambientais na Baía de Paranaguá. Nerítica, 8(1-2):55-72.

Brandini, F. P.; Thamm, C. A. \& Ventura, I. 1988. Ecological studies in the Bay of Paranaguá. III. Seasonal and spatial variations of nutrients and chlorophyll-a. Nerítica, 3(1):1-30.

Camacho-Ibar, V. F.; Dupra, V.; Marshall-Crossland, J. I.; Wulff, F.; Smith, S. V. \& Crossland, C. J. eds. 2002. Estuarine Systems of the Latin American Region (Regional Workshop V), and estuarine systems of the Arctic Region: carbon, nitrogen and phosphorus fluxes. LOICZ Reports and Studies No. 23, 96 p.

Chisholm, L. A. \& Roff, J. C. 1990. Size-weight relationships and biomass of tropical neritic copepods off Kingston, Jamaica. Mar. Biol., 104:71-77. 
Costa, J. E.; Howes, B. L.; Janik, D.; Aubrey, D.; Gunn, E. \& Giblin, A. E. 1999. Managing anthropogenic nitrogen inputs to coastal embayments: Technical basis of a management strategy adopted for Buzzards Bay. Buzzards Bay Project Technical Report, 62 p.

Christian, R. R. \& Thomas, C. R. 2000. Neuse River Estuary modeling and monitoring project Stage 1: Network analysis for evaluating the consequences of nitrogen loading. Water Resources Research Institute of The University of North Carolina Report No. 325-F. Raleigh, NC.

Dam, H. G. \& Peterson, W. T. 1993. Seasonal contrasts in the diel vertical distribution, feeding behaviour, and grazing impact of the copepod Temora longicornis in Long Island Sound. J. Mar. Res., 51:561-594.

Day, J. W.; Smith, W. G.; Wagner, P. R. \& Stowe, W. 1973. Community structure and carbon budget of a salt marsh and shallow bay estuarine system in Louisiana. Center for Wetland Resources, Louisiana State University, Baton Rouge, Publ. LUS-SG-72-04.

Deibel, D. 1985. Clearance rates of the salp Thalia democratica fed naturally occurring particles. Mar. Biol., 86:47-54.

Deibel, D. 1988. Filter feeding by Oikopleura vanhoeffeni: grazing impact on suspended particles in cold ocean waters. Mar. Biol., 99:177-186.

FEEMA. 1987. Qualidade das águas do estado do Rio de Janeiro. Rio de Janeiro: FEEMA, 86 p. v. 2.

Feigenbaum, D. 1979. Daily ration and specific daily ration of the chaetognath Sagitta enflata. Mar. Biol., 54:75-82.

Gordon Jr., D. C.; Boudreau, P. R.; Mann, K. H.; Ong, J.-E., Silvert, W. L.; Smith, S. V.; Wattayakorn, G.; Wullf, F. \& Yanagi, T. 1996. LOICZ Biogeochemical Modelling Guidelines. LOICZ Reports and Studies No 5, 1-96.

Ikeda, T. 1985. Metabolic rates of epipelagic marine zooplankton as a function of body mass and temperature. Mar. Biol., 85:1-11.

IPARDES, 1989. Zoneamento do Litoral Paranaense. Instituto Paranaense de Desenvolvimento Econômico e Social. Fund. Édison Vieira. Curitiba, Julho de 1989. 176 pp.

Jørgensen, S. E. 1994. Fundamentals of ecological modelling ( $2^{\text {nd }}$ edition). Developments in Environmental Modelling, 19, New York, 628 p.

Kelly, J. R. 1998. Quantification and potential role of ocean nutrient loading to Boston Harbor, Massachusetts, USA. Marine Ecology Progress Series.173:53-65.

Knoppers, B. A.; Brandini, F. P. \& Thamm, C. A. 1987. Ecological studies in the Bay of Paranaguá. II. some physical and chemical characteristics. Nerítica 2(1):136.

Kuypers, M. M. M.; Sliekers, A. O.; Lavik, G.; Schmid, M.; Jørgensen, B. B.; Kuenen, J. G.; Damste, J. S. S.; Strous, M.; Mike, S. M. \& Jetten, M. S. M. 2003. Anaerobic ammonium oxidation by anammox bacteria in the Black Sea. Nature, 422:608-611.

Lana, P. C.; Marone, E.; Lopes, R. M. \& Machado, E. C. 2000. The subtropical estuarine complex of Paranaguá Bay, Brazil. In: Coastal Marine Ecosystems of Latin America, Seeliger, U., Lacerda, L.D. \& Kjerfve, B. (eds.), Springer Verlag, NY, USA, 467pp.

Lopes, R. M. 1997. Zooplâncton da Baía de Paranaguá: distribuição espacial, variação temporal e interações tróficas. Thesis, Zoology Dept., UFPR, 145p.
Lopes, R. M.; Vale, R. \& Brandini, F. P. 1998. Composição, abundância e distribuição espacial do zooplâncton no complexo estuarino de Paranaguá durante o inverno de 1993 e o verão de 1994. Rev. Bras. Oceanogr., 46:195211.

Machado, E. C.; Daniel, C. B.; Brandini, N. \& Queiroz, R. L. V. 1997. Temporal and spatial dynamics of nutrients and particulate suspended matter in Paranaguá Bay, PR, Brazil. Nerítica, 11:15-34.

Marone, E. \& Camargo, R. 1994. Efeitos de maré meteorológica na Baía de Paranaguá, PR. Neritica, 8(12):73-85.

Marone, E.; Guimarães, M. R.; Prata Jr., V. P.; Klingenfuss, M. S. \& Camargo, R. 1995. Caracterização Física das Condições Oceanográficas, Meteorológicas e Costeiras das Zonas Estuarinas da Baía de Paranaguá, PR. Anales del VI Congreso Latinoamericano de Ciencias del Mar. Mar del Plata, Argentina, 57-61p.

Marone, E.; Mantovanelli, A.; Klingenfuss, M. S.; Lautert, L. F. C. \& Prata Jr., V. P. 1997. Transporte de material particulado em suspensão, água, sal e calor na Gamboa do Perequê num evento de maré de sizígia. Anales del VII Congreso Latinoamericano de Ciencias del Mar. Santos, Brazil, 132-135p.

Montú, M. \& Cordeiro, T. A. 1988. Zooplancton del complejo estuarial de la Bahia de Paranaguá. I. Composición, dinámica de las especies, ritmos reproductivos y acción de los factores ambientales sobre la comunidad. Nerítica 3:61-83.

Nowicki, B. L.; Kelly, J. R.; Requintina, E. \& Van Keuren, D. 1997. Nitrogen losses through sediment denitrification in Boston Harbor and Massachusetts Bay. Estuaries 20:626-639.

Paffenhöfer, G.-A. 1976. On the biology of Appendicularia of the southeastern North Sea. In: Persoone, G. \& Jaspers, E. eds. $10^{\text {th }}$ European Symposium on Marine Biology. Vol. 2, Universa Press, Belgium, p. 437-455.

Pearre, S. 1982. Feeding by Chaetognatha: aspects of interand intra-specific predation. Mar. Ecol. Prog. Ser., 7:3345 .

Rebello, J. \& Brandini, F. P. 1990. Variação temporal de parâmetros hidrográficos e material particulado em suspensão em dois pontos fixos da Baía de Paranaguá, Paraná (junho/87 - fevereiro/88). Nerítica 5(1):95-111.

Rezende, K. R. V. 1995. Dinâmica temporal do fitoplâncton de zona de arrebentação da Praia de Pontal do Sul (Paraná). M.Sc. Dissertation, Inst. Oceanogr., Univ. S. Paulo, $130 \mathrm{p}$.

San Diego-Mcglone, M. L.; Smith, S.V. \& Nicolas, V. 1999. Stoichiometric Interpretations of $\mathrm{C}: \mathrm{N}: \mathrm{P}$ Ratios in Organic Waste Materials. Marine Pollution Bulletin 40: 325-330.

Seitzinger, S. P. 1988. Denitrification in freshwater and coastal marine ecosystems: ecological and geochemical significance. Limnol. Oceanog. 33:702-724.

Smith, S. V.; Ibarra-Obando, S.; Boudreau, P. R. \& Camacho-Ibar, V. F. 1997. Comparison of Carbon, Nitrogen and Phosphorus Fluxes in Mexican Coastal Lagoons, LOICZ Reports \& Studies No. 10, ii + 84 pp. Texel, The Netherlands.

Soares, C. R. \& Marone, E. 1997. Relatório Consolidado Convênio APPA-CEM. Curitiba. 580 p. 
Teixeira, C.; Tundisi, J. \& Santoro, J. Y. 1969. Plankton studies in a mangrove environment. VI. Primary production, zooplankton standing-stock and some environmental factors. Int. rev. ges. Hydrobiol., 53:289301 .

UNESCO United Nations Educacional, Scientific and Cultural Organization. 1985. The International System of Units (SI) in oceanography. IAPSO Publication Scientifique, Paris, 32:1-124.

Webber, M. K. \& Roff, J. C. 1995. Annual biomass and production of the oceanic copepod community off Discovery Bay, Jamaica. Mar. Biol., 123:481-495.

Wiebe, P. H.; Boyd, S. \& Cox, J. L. 1975. Relationships between zooplankton displacement volume, wet weight, dry weight and carbon. Fish. Bull., 73(4): 777-786.
Wollast, R. 1993. Interactions of carbon and nitrogen cycles in the coastal zone. In: Interactions of $\mathrm{C}, \mathrm{N}, \mathrm{P}$ and $\mathrm{S}$ Biogeochemical Cycles and Global Change (R. Wollast,

F. T. Mackenzie \& L. Chou, eds.). Springer- Verlag Berlin Heidelberg. NATO ASI Series I (4):401-445.

Zehrl, J. P \& Ward, B. B. 2002. Nitrogen Cycling in the Ocean: New Perspectives on Processes and Paradigms. Applied and Environmental Microbiology: 1015-1024.

(Manuscript received 04 March 2004; revised 22 September 2005; accepted 03 December 2005) 